\title{
STUDI SERANGAN ANTRAKNOSA PADA PERTUMBUHAN CABAI MERAH (Capsicum annuum L.) SETELAH APLIKASI LARUTAN DAUN MIMBA DAN MOL BONGGOL PISANG
}

\author{
Study of Anthracnosa Attack on the Growth of Red Chili (Capsicum annuum L.) after \\ Application of the Neem Leaves Solution and Local Microorganism of Banana Hump \\ Muhammad Hifniy Aziziy', Oktavianus Lumban Tobing², Yanyan Mulyaningsih* \\ ${ }^{1}$ Program Studi Agroteknologi, Fakultas Pertanian Universitas Djuanda Bogor \\ ${ }^{2}$ Staf Pengajar Program Studi Agroteknologi, Fakultas Pertanian, Universitas Djuanda Bogor \\ Jl. Tol Ciawi 1, Kotak Pos 35 Bogor 16720 \\ *E-mail : yanyan.mulyaningsih@unida.ac.id
}

\section{Diterima 31 Maret 2020/Disetujui 30 April 2020}

\begin{abstract}
ABSTRAK
Antraknosa merupakan salah satu penyakit utama yang menyerang tanaman cabai merah (Capsicum annuum L.) sehingga dapat menurunkan produktivitas. Penggunaan fungisida nabati dan mikroorganisme dapat mengurangi persentase serangan antraknosa pada cabai merah tanpa menimbulkan dampak negatif terhadap lingkungan. Penelitian ini bertujuan yaitu untuk mengetahui potensi larutan daun mimba dan MOL bonggol pisang dengan dosis yang tepat dalam mengendalikan penyakit antraknosa serta meningkatkan pertumbuhan dan hasil pada tanaman cabai merah. Model penelitian yang digunakan yaitu Rancangan Acak Kelompok Faktorial yang terdiri atas dua faktor yaitu konsentrasi larutan daun mimba $(0 \%, 15 \%, 30 \%, 45 \%)$ dan konsentrasi MOL bonggol pisang $(0 \%, 15 \%, 30 \%$, 45\%). Hasil penelitian menunjukkan bahwa konsentrasi larutan daun mimba tidak memberikan pengaruh yang nyata terhadap semua peubah yang diamati. Konsentrasi larutan MOL bonggol pisang $45 \%$ berpengaruh nyata dalam meningkatkan tinggi tanaman, jumlah daun, jumlah cabang produktif dan bobot buah per tanaman dibandingkan dengan perlakuan kontrol, namun tidak berbeda nyata dibandingkan dengan konsentrasi 30\%. Pada penelitian ini tidak terjadi serangan antraknosa terhadap semua tanaman yang diamati pada semua perlakuan, artinya persentase kejadian penyakit dan tingkat keparahan penyakit adalah $0 \%$. Hal tersebut terjadi diduga karena faktor lingkungan yang tidak mendukung untuk perkembangan jamur Colletotrichum sp.
\end{abstract}

Kata kunci: Capsicum annuum, Colletotrichum, mimba, bonggol pisang

\section{ABSTRACT}

Anthracnose is one of the main diseases that attacks the chili peppers plant (Capsicum annuum L.) so that it can reduce productivity. The use of plant-based fungicides and microorganisms can reduce the percentage of anthracnose attacks on chili peppers without causing a negative impact on the environment. This study aims to determine the potential of the neem leaves solution and local microorganism of banana hump with the right dose in controlling anthracnose disease and increasing growth and yield in chili peppers plants. The research model used is a factorial randomized block design consisting of two factors: consentration of neem leaves solution $(0 \%, 15 \%, 30 \%, 45 \%)$ and consentration of local microorganism of banana hump $(0 \%, 15 \%, 30 \%, 45 \%)$. The results of this study show the fact that the concentration of neem leaves solution does not provide significant results for all parameters. The concentration of local microorganism of banana hump $45 \%$ was more 
significant in increasing plant height, number of leaves, number of productive branches and fruit weight per plant compared to control settings, but not significantly different from the concentration of $30 \%$. This study didn't occur anthracnose attacks on all plants that are reflected in all assistance, meaning that the percentage of disease incidents and the severity of the disease is 0\%. This happens due to environmental factors that do not support the development of the fungus Colletotrichum sp.

Keywords: Capsicum annuum, Colletotrichum, neem, banana hump

\section{PENDAHULUAN}

Cabai merah (Capsicum annuum L.) merupakan jenis tanaman hortikultura kelompok sayuran buah yang bernilai ekonomi tinggi. Cabai merah biasa digunakan sebagai bumbu dapur, selain itu cabai merah umum digunakan sebagai bahan baku dalam industri pangan dan farmasi, sehingga komoditas ini memiliki peluang yang baik dalam hal pemasaran. Produktivitas cabai merah nasional tahun 2016 adalah 8,47 $\mathrm{t} \mathrm{ha}^{-1}$, sedangkan pada tahun 2017 menurun sebesar $0,11 \%$ menjadi 8,46 t ha-1 (BPS 2018).

Antraknosa merupakan salah satu jenis penyakit utama tanaman cabai merah yang disebabkan oleh adanya infeksi jamur Colletotrichum sp. Antraknosa dapat menyebabkan dieback atau mati pucuk pada tanaman dewasa yang kemudian diikuti infeksi pada buah, sehingga pada akhirnya menurunkan produktivitas tanaman cabai (Prasetyo 2017). Menurut BPPP (2016), antraknosa yang menyerang tanaman cabai dapat menyebabkan kehilangan hasil hingga 90\% terutama jika terjadi pada saat musim hujan.

Pengendalian penyakit antraknosa saat ini masih bergantung pada penggunaan fungisida sintetik secara intensif. Penggunaan fungisida sintetik untuk mengendalikan penyakit antraknosa dapat menimbulkan dampak negatif dalam jangka panjang (Suleiman 2010). Oleh karena itu, untuk mengatasi dampak negatif penggunaan fungisida sintetik tersebut dapat digunakan fungisida berbahan nabati. Fungisida nabati tergolong ramah lingkungan dan aman karena bahan baku yang digunakan berasal dari tumbuhan yang mudah terurai di alam. Keunggulan lain penggunaan bahan nabati adalah lebih murah, mudah diperoleh dan mudah diaplikasikan.

Mimba (Azadirachta indica A. Juss) merupakan tanaman yang memiliki sifat antifungi. Ekstrak daun mimba diketahui mengandung bahan aktif nimbin, nimbidin, solanin, azadirachtin dan melantriol yang berfungsi sebagai fungisida (Agustin et al. 2016). Ekstrak berbagai bagian tanaman mimba juga telah terbukti menjadi racun bagi jamur patogen seperti Pyricularia oryzae yang menginfeksi tanaman padi dan padi yang telah dipanen (Amadioha 2000).

Selain menggunakan fungisida nabati, penggunaan mikroorganisme seperti Bacillus sp. dapat dijadikan alternatif dalam mengendalikan penyakit suatu tanaman. Menurut Susanto et al. (2005), mikroorganisme seperti Bacillus sp. dapat menghasilkan senyawa yang bersifat antifungi.

Salah satu pemanfaatan mikroorganisme dalam mengendalikan serangan penyakit yaitu dengan menggunakan Mikroorganisme Lokal (MOL) yang terbuat dari bonggol pisang. Bonggol pisang mengandung mikroba yang berguna bagi tanaman seperti Azotobacter, Azospirillum, Bacillus sp., Aeromonas sp. dan Aspergillus nigger. Selain itu, bonggol pisang juga diketahui mengandung hormon sitokinin dan giberelin (Wea 2018). Penelitian Nasrun dan Nurmansyah (2015), menunjukkan penggunaan rhizobacteria (Bacillus sp. dan Pseudomonas fluorescens) dan kombinasi 
bahan aktif fungisida nabati mampu menghambat pertumbuhan jamur Rigidoporus microporus penyebab penyakit akar putih pada tanaman karet hingga $90 \%$.

Penelitian ini bertujuan untuk mengetahui potensi larutan daun mimba dan MOL bonggol pisang dengan dosis yang tepat dalam mengendalikan penyakit antraknosa dan meningkatkan pertumbuhan serta hasil tanaman cabai merah.

\section{BAHAN DAN METODE}

Penelitian dilaksanakan pada bulan April-Agustus 2019. Penanaman dilakukan di kebun kelompok tani Repeh Rapih Desa Sukamantri, Kecamatan Tamansari, Kabupaten Bogor, Jawa Barat. Pengamatan mikroskopis dilakukan di Laboratorium Biologi, Universitas Djuanda Bogor.

Alat yang digunakan pada penelitian ini adalah alat budidaya, ember, pisau, gembor, meteran, ajir, kaca preparat, silet, mikroskop dan alat tulis. Bahan yang digunakan yaitu paranet $40 \%$, polybag ukuran $5 \times 12 \mathrm{~cm}$ dan $30 \times 40 \mathrm{~cm}$, double tape, tali, benih cabai varietas gada $\mathrm{F} 1$, daun mimba, bonggol pisang varietas kepok, air cucian beras, gula merah, pupuk kandang (sapi), sekam bakar, tanah dan air.

\begin{tabular}{cccr}
\multicolumn{2}{c}{ Rancangan } & penelitian & yang \\
digunakan & adalah & Rancangan & Acak \\
Kelompok & (RAK) & faktorial. & Faktor
\end{tabular}

pertama merupakan larutan daun mimba dengan empat taraf yaitu M0 atau kontrol $(0 \%=100 \mathrm{ml}$ air $), \mathrm{M} 1 \quad(15 \%=15 \mathrm{ml}$ larutan $+85 \mathrm{ml}$ air $), \mathrm{M} 2(30 \%=30 \mathrm{ml}$ larutan $+70 \mathrm{ml}$ air $)$ dan M3 $(45 \%=45 \mathrm{ml}$ larutan $+55 \mathrm{ml}$ air). Faktor kedua adalah MOL bonggol pisang dengan empat taraf yaitu $\mathrm{P} 0$ atau kontrol $(0 \%=100 \mathrm{ml}$ air $)$, $\mathrm{P} 1(15 \%=15 \mathrm{ml} \mathrm{MOL}+85 \mathrm{ml}$ air $), \mathrm{P} 2$ $(30 \%=30 \mathrm{ml} \mathrm{MOL}+70 \mathrm{ml}$ air $)$ dan $\mathrm{P} 3$ $(45 \%=45 \mathrm{ml} \mathrm{MOL}+55 \mathrm{ml}$ air $)$. Dengan demikian pada percobaan ini terdapat 16 kombinasi perlakuan $\times 3$ ulangan $\times 3$ tanaman $=144$ satuan amatan.

Peubah yang diamati meliputi tinggi tanaman, jumlah daun, jumlah cabang, kejadian penyakit antraknosa, keparahan penyakit antraknosa, epidemi penyakit antraknosa dan komponen hasil panen seperti bobot buah per tanaman $(\mathrm{g})$, jumlah buah per tanaman, panjang buah $(\mathrm{cm})$ dan diameter buah $(\mathrm{cm})$.

Pembuatan larutan daun mimba dilakukan dengan menghaluskan 100 gram daun mimba yang telah dicuci bersih. Daun mimba yang telah halus dilarutkan dengan air sebanyak 1 liter dan didiamkan selama 24 jam. Pembuatan MOL dilakukan dengan menggunakan teknik fermentasi. Bonggol pisang dicuci bersih sebanyak $5 \mathrm{~kg}$, kemudian dipotong kecil. Gula merah sebanyak $1 \mathrm{~kg}$ diiris halus dan dilarutkan kedalam 10 liter air cucian beras di dalam ember lalu dicampurkan dengan potongan bongol dan difermentasi selama 14 hari.

Tabel 1 Kondisi lingkungan selama penelitian

\begin{tabular}{lcccc}
\hline Parameter & April & Mei & Juni & Juli \\
\hline Temperatur Minimum $\left({ }^{\circ} \mathrm{C}\right)$ & 22,0 & 22,2 & 20,2 & 19,3 \\
Temperatur Maksimum $\left({ }^{\circ} \mathrm{C}\right)$ & 34,1 & 33,8 & 33,9 & 33,7 \\
Temperatur Rata-rata $\left({ }^{\circ} \mathrm{C}\right)$ & 26,5 & 27,1 & 26,4 & 25,8 \\
Kelembapan Rata-rata $(\%)$ & 85,0 & 81,3 & 80,0 & 77,2 \\
Curah Hujan $(\mathrm{mm} /$ bulan) & 565 & 236,7 & 137,5 & 52,4 \\
\hline
\end{tabular}

Sumber : BMKG 2019 


\section{HASIL DAN PEMBAHASAN}

\section{Keadaan Umum}

Selama penelitian berlangsung, kondisi lingkungan bervariasi dan suhu rata-rata per bulan adalah $26,4{ }^{\circ} \mathrm{C}$ (Tabel $1)$.

\section{Hasil Pengamatan}

Tinggi Tanaman

Konsentrasi larutan daun mimba tidak memberikan pengaruh yang nyata terhadap tinggi tanaman cabai merah, sedangkan pemberian MOL bonggol pisang konsentrasi $45 \%$ dan $30 \%$ menunjukkan hasil yang nyata lebih besar dibandingkan dengan perlakuan kontrol, tetapi antara konsentrasi MOL 15\%, 30\% dan $45 \%$ menunjukkan hasil tidak berbeda nyata.

Antara konsentrasi MOL 15\% dan perlakuan kontrol tidak menunjukkan hasil yang berbeda nyata. Kedua perlakuan tidak menunjukkan adnya interaksi (Tabel 2).

Tabel 2 Tinggi tanaman $(\mathrm{cm})$ cabai merah pada umur 15-57 HSPT

\begin{tabular}{|c|c|c|c|c|c|c|c|}
\hline \multirow{2}{*}{ Perlakuan } & \multicolumn{7}{|c|}{ Umur Tanaman (HSPT) } \\
\hline & 15 & 22 & 29 & 36 & 43 & 50 & 57 \\
\hline Larutan Daun Mimba & & & $---\cdot$ & $-\mathrm{cm}-$ & ------ & --------- & \\
\hline Kontrol & 15,95 & 23,14 & 27,36 & 32,55 & 35,46 & 40,16 & 41,95 \\
\hline $15 \%$ & 16,39 & 23,84 & 28,89 & 33,28 & 36,74 & 40,74 & 42,91 \\
\hline $30 \%$ & 16,63 & 24,13 & 29,53 & 34,02 & 37,11 & 41,29 & 43,30 \\
\hline $45 \%$ & 17,26 & 24,68 & 30,32 & 34,59 & 38,01 & 42,34 & 44,42 \\
\hline MOL Bonggol Pisang & & & & & & & \\
\hline Kontrol & 15,87 & 22,17 & $25,82^{\mathrm{a}}$ & $29,97^{\mathrm{a}}$ & $33,03^{\mathrm{a}}$ & $36,76^{\mathrm{a}}$ & $38,43^{\mathrm{a}}$ \\
\hline $15 \%$ & 16,30 & 23,81 & $28,50^{\mathrm{ab}}$ & $32,46^{\mathrm{ab}}$ & $35,50^{\mathrm{ab}}$ & $39,65^{\mathrm{ab}}$ & $41,66^{\mathrm{ab}}$ \\
\hline $30 \%$ & 16,41 & 24,85 & $30,82^{b}$ & $35,58^{\mathrm{b}}$ & $38,99^{\mathrm{b}}$ & $43,07^{\mathrm{ab}}$ & $45,23^{\mathrm{b}}$ \\
\hline $45 \%$ & 17,65 & 24,94 & $30,96^{\mathrm{b}}$ & $36,44^{\mathrm{b}}$ & $39,80^{\mathrm{b}}$ & $45,06^{\mathrm{b}}$ & $47,27^{\mathrm{b}}$ \\
\hline
\end{tabular}

Keterangan: Nilai rata-rata pada kolom yang sama diikuti huruf yang sama menunjukkan tidak berbeda nyata berdasarkan hasil uji DMRT pada taraf 5\%.

Jumlah Daun

Jumlah daun tanaman cabai merah nyata dipengaruhi oleh konsentrasi MOL bonggol pisang, tetapi tidak dipengaruhi oleh konsentrasi larutan daun mimba. Kedua perlakuan tidak menunjukkan adanya interaksi (Tabel 3).

Tabel 3 Jumlah daun (helai) cabai merah pada umur 15-57 HSPT

\begin{tabular}{|c|c|c|c|c|c|c|c|}
\hline \multirow{2}{*}{ Perlakuan } & \multicolumn{7}{|c|}{ Umur Tanaman (HSPT) } \\
\hline & 15 & 22 & 29 & 36 & 43 & 50 & 57 \\
\hline Larutan Daun Mimba & \multicolumn{7}{|c|}{ 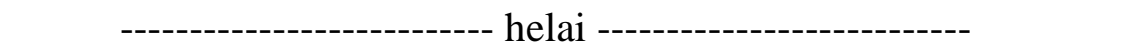 } \\
\hline Kontrol & 17,44 & 37,31 & 62,86 & 102,67 & 138,64 & 158,22 & 176,64 \\
\hline $15 \%$ & 18,47 & 44,83 & 71,64 & 113,17 & 156,22 & 177,25 & 195,78 \\
\hline $30 \%$ & 18,50 & 45,22 & 73,00 & 114,72 & 166,39 & 186,53 & 205,28 \\
\hline $45 \%$ & 18,89 & 46,08 & 73,94 & 115,14 & 167,19 & 187,72 & 206,92 \\
\hline \multicolumn{8}{|l|}{ MOL Bonggol Pisang } \\
\hline Kontrol & 16,39 & 36,25 & $58,56^{\mathrm{a}}$ & $94,11^{\mathrm{a}}$ & $124,64^{\mathrm{a}}$ & $145,92^{\mathrm{a}}$ & $164,28^{\mathrm{a}}$ \\
\hline $15 \%$ & 18,64 & 45,22 & $70,36^{\mathrm{ab}}$ & $107,86^{\mathrm{ab}}$ & $149,19^{\mathrm{ab}}$ & $170,14^{\mathrm{ab}}$ & $189,75^{\mathrm{ab}}$ \\
\hline $30 \%$ & 19,06 & 45,50 & $73,00^{\mathrm{ab}}$ & $116,11^{\mathrm{ab}}$ & $169,33^{b c}$ & $190,67^{\mathrm{bc}}$ & $209,36^{\mathrm{b}}$ \\
\hline $45 \%$ & 19,22 & 46,47 & $79,53^{\mathrm{b}}$ & $127,61^{\mathrm{b}}$ & $185,28^{\mathrm{c}}$ & $203,00^{c}$ & $221,22^{\mathrm{b}}$ \\
\hline
\end{tabular}

Keterangan: Nilai rata-rata pada kolom yang sama diikuti huruf yang sama menunjukkan berbeda nyata berdasarkan hasil uji DMRT pada taraf 5\%. 
Pemberian MOL konsentrasi 15\% tidak menunjukkan hasil yang berbeda nyata dengan perlakuan kontrol. Konsentrasi MOL 30\% nyata lebih besar dibandingkan perlakuan kontrol pada umur 43-57 HSPT, tetapi tidak berbeda nyata pada umur 29 HSPT dan 36 HSPT.

Konsentrasi MOL $15 \%$ dengan $30 \%$ tidak menunjukkan hasil yang berbeda nyata. Konsentrasi MOL $45 \%$ menunjukkan hasil yang nyata lebih besar dibandingkan dengan perlakuan kontrol pada umur 29-57 HSPT. Konsentrasi MOL $45 \%$ dengan konsentrasi $15 \%$ tidak berbeda nyata pada umur 29 HSPT, 36
HSPT dan 57 HSPT, namun berbeda nyata pada umur 43 HSPT dan 50 HSPT. Konsentrasi MOL $45 \%$ dan $30 \%$ menunjukkan hasil yang tidak berbeda nyata.

\section{Jumlah Cabang Produktif \\ Jumlah cabang produktif tanaman cabai merah nyata dipengaruhi oleh konsentrasi MOL bonggol pisang, tetapi konsentrasi larutan daun mimba tidak menunjukkan pengaruh yang nyata. Kedua perlakuan tidak menunjukkan adanya interaksi (Tabel 4).}

Tabel 4 Jumlah cabang produktif pada umur 15-57 HSPT

\begin{tabular}{lccccccc}
\hline \multirow{2}{*}{ Perlakuan } & \multicolumn{7}{c}{ Umur Tanaman (HSPT) } \\
\cline { 2 - 8 } & 15 & 22 & 29 & 36 & 43 & 50 & 57 \\
\hline Larutan Daun Mimba & & & & & & & \\
Kontrol & 4,39 & 9,55 & 19,17 & 32,78 & 44,83 & 52,50 & 59,22 \\
$15 \%$ & 5,11 & 9,89 & 19,94 & 34,89 & 46,28 & 52,89 & 59,78 \\
$30 \%$ & 5,17 & 10,00 & 19,72 & 34,33 & 47,11 & 54,61 & 61,83 \\
$45 \%$ & 5,33 & 10,06 & 21,56 & 33,83 & 46,11 & 53,83 & 60,72 \\
\hline MOL Bonggol Pisang & & & & & & & \\
Kontrol & 4,45 & 9,50 & $18,06^{\mathrm{a}}$ & $30,67^{\mathrm{a}}$ & $42,94^{\mathrm{a}}$ & 51,83 & 58,89 \\
$15 \%$ & 5,06 & 9,83 & $19,67^{\mathrm{ab}}$ & $33,11^{\mathrm{ab}}$ & $45,06^{\mathrm{ab}}$ & 53,22 & 60,17 \\
$30 \%$ & 5,22 & 9,94 & $20,67^{\mathrm{ab}}$ & $35,56^{\mathrm{bc}}$ & $47,67^{\mathrm{bc}}$ & 53,83 & 60,67 \\
$45 \%$ & 5,28 & 10,22 & $22,00^{\mathrm{b}}$ & $36,50^{\mathrm{c}}$ & $48,67^{\mathrm{c}}$ & 54,95 & 61,83 \\
\hline
\end{tabular}

Keterangan: Nilai rata-rata pada kolom yang sama diikuti huruf yang sama menunjukkan tidak berbeda nyata berdasarkan hasil uji DMRT pada taraf $5 \%$.

Pemberian MOL konsentrasi 15\% tidak menunjukkan hasil yang berbeda nyata dengan perlakuan kontrol dan konsentrasi $30 \%$, tetapi konsentrasi MOL $30 \%$ berbeda nyata dengan perlakuan kontrol pada umur tanaman 36 HSPT dan 43 HSPT. Konsentrasi MOL $45 \%$ menunjukkan hasil yang berbeda nyata dibandingkan dengan perlakuan kontrol pada umur tanaman 29 HSPT, 36 HSPT dan 43 HSPT, serta berbeda nyata dibandingkan dengan konsentrasi $15 \%$ pada umur tanaman 36 HSPT dan 43 HSPT. Konsentrasi MOL $45 \%$ dengan $30 \%$ menunjukkan hasil yang tidak berbeda nyata.
Kejadian dan Keparahan Penyakit

Menurut Endah dan Novizan (2002), buah cabai yang terinfeksi penyakit antraknosa oleh jamur Colletotrichum capsici menunjukkan gejala berupa bercak cokelat kehitaman yang berkembang menjadi busuk lunak dan terdapat titik-titik hitam di bagian tengah bercak. Hasil pengamatan yang dilakukan selama penelitian, menunjukkan bahwa semua tanaman yang diamati pada semua perlakuan, tidak terdapat gejala serangan penyakit antraknosa, artinya persentase kejadian penyakit dan tingkat keparahan penyakit adalah $0 \%$. 
Komponen Hasil

Pemberian berbagai konsentrasi larutan daun mimba tidak bepengaruh nyata pada semua peubah komponen hasil panen. Sementara itu, pemberian berbagai konsentrasi MOL bonggol pisang tidak menunjukkan pengaruh yang nyata terhadap peubah jumlah buah per tanaman, panjang buah dan diameter buah, tetapi memberikan pengaruh yang nyata terhadap peubah bobot buah per tanaman. Di antara kedua perlakuan tidak ada interaksi yang nyata (Tabel 5).

Pemberian MOL pada konsentrasi $15 \%$ dan $30 \%$ tidak menunjukkan hasil yang berbeda nyata dibandingkan dengan perlakuan kontrol pada peubah bobot buah. Konsentrasi $45 \%$ menunjukkan hasil yang nyata lebih besar dibandingkan dengan konsentrasi $15 \%$ dan perlakuan kontrol, tetapi tidak berbeda nyata dengan konsentrasi $30 \%$.

Tabel 5. Komponen hasil panen cabai merah

\begin{tabular}{lcccc}
\hline \multicolumn{1}{c}{ Perlakuan } & $\begin{array}{c}\text { Bobot Buah Per } \\
\text { Tanaman (g) }\end{array}$ & $\begin{array}{c}\text { Jumlah } \\
\text { Buah Per } \\
\text { Tanaman }\end{array}$ & $\begin{array}{c}\text { Panjang } \\
\text { Buah (cm) }\end{array}$ & $\begin{array}{c}\text { Diameter } \\
\text { Buah (cm) }\end{array}$ \\
\hline $\begin{array}{l}\text { Larutan Daun Mimba } \\
\text { Kontrol }\end{array}$ & 45,56 & 11,86 & 10,25 & 1,11 \\
$15 \%$ & 46,95 & 12,83 & 10,63 & 1,10 \\
$30 \%$ & 47,04 & 13,17 & 10,47 & 1,10 \\
$45 \%$ & 50,03 & 13,83 & 10,37 & 1,12 \\
\hline MOL Bonggol Pisang & & & & \\
Kontrol & $43,65^{\mathrm{a}}$ & 12,25 & 10,29 & 1,10 \\
$15 \%$ & $44,08^{\mathrm{a}}$ & 12,19 & 10,37 & 1,11 \\
$30 \%$ & $48,66^{\mathrm{ab}}$ & 13,36 & 10,62 & 1,12 \\
$45 \%$ & $53,20^{\mathrm{b}}$ & 13,89 & 10,44 & 1,11 \\
\hline
\end{tabular}

Keterangan: Nilai rata-rata pada kolom yang sama diikuti huruf yang sama menunjukkan tidak berbeda nyata berdasarkan hasil uji DMRT pada taraf 5\%.

\section{Pembahasan}

\section{Pertumbuhan Tanaman Cabai Merah}

Konsentrasi MOL $45 \%$

menunjukkan hasil tinggi tanaman yang berbeda nyata dengan perlakuan kontrol namun tidak berbeda nyata dengan perlakuan lainnya. Wea (2018), menyatakan bahwa bonggol pisang memiliki kandungan hormon sitokinin dan giberelin yang berperan dalam meningkatkan pertumbuhan tanaman.

Jumlah daun pada konsentrasi MOL 45\% tidak berbeda nyata dengan konsentrasi $30 \%$, namun keduanya berbeda nyata dengan perlakuan kontrol. Penelitian Wea (2018), menunjukkan bahwa bonggol pisang berpengaruh nyata terhadap jumlah daun pada tanaman okra merah (Abelmoschus caillei) dengan jumlah daun terbanyak terdapat pada konsentrasi $300 \mathrm{ml} \mathrm{l}^{-1}$ (30\%). Kandungan hormon sitokinin diduga berperan dalam meningkatakan pertumbuhan jumlah daun tanaman cabai merah. Hormon sitokonin berperan dalam pembelahan sel. Jika konsentrasi sitokinin yang diserap tanaman lebih besar daripada auksin, maka akan memperlihatkan pertumbuhan tunas dan daun (Kurniati et al. 2017).

Konsentrasi

MOL $45 \%$ menunjukkan hasil jumlah cabang produktif yang tidak berbeda nyata dengan konsentrasi $30 \%$. Menurut Kurniati et al. (2017), dalam $100 \mathrm{ml}$ ekstrak bonggol pisang mengandung hormon sitokinin berupa kinetin 3,620 ppm dan zeatin 2,4 ppm. Hormon sitokinin seperti kinetin berfungsi dalam proses pembelahan sel, morfogenesis dan pertumbuhan tunas pada tanaman (Nursyamsi et al. 2007). Suhastyo (2011), menyatakan bahwa kandungan $\mathrm{N}$ total dapat meningkat dengan adanya 
pemberian MOL bonggol pisang. Peningkatan kandungan $\mathrm{N}$ diduga karena adanya aktivitas mikroorganisme yaitu Bacillus sp. dalam proses dekomposisi. Bacillus sp. juga berperan dalam nitrifikasi dan denitrifikasi, sehingga unsur $\mathrm{N}$ yang ada mampu diserap dan dimanfaatkan dengan baik oleh tanaman. Unsur hara $\mathrm{N}$ sangat diperlukan pada pertumbuhan tanaman terutama pada fase pertumbuhan cabang-cabang pada tanaman. Azotobacter dalam MOL bonggol pisang juga dapat meningkatkan pertumbuhan vegetatif tanaman (Budiyani et al. 2016). Bakteri ini menghasilkan senyawa eksopolisakarida (EPS) dan asam lemak, yang mampu memperbaiki perkembangan akar karena menghasilkan fitohormon golongan auksin dan sitokinin. Azospirillum juga dapat menghasilkan fitohormon, fiksasi nitrogen, produksi nitrit dan meningkatkan penyerapan mineral oleh tanaman (Waskito et al. 2018).

\section{Kejadian dan Keparahan Penyakit}

Tidak terjadinya serangan antraknosa pada penelitian ini disebabkan oleh beberapa faktor. Menurut Islam (2018), ada tiga faktor yang menyebabkan suatu tanaman terserang penyakit. Faktor pertama adalah adanya patogen atau sumber penyakit. Penelitian yang dilakukan bersifat alami, artinya tanaman cabai merah tidak diinokulasi isolat jamur Colletotrichum sp., sehingga peluang terjadi serangan penyakit antraknosa lebih kecil. Meskipun begitu, pada kasus ini, di sekitar tempat penelitian terdapat kebun cabai merah milik petani setempat, serta pada periode sebelumnya juga telah beberapa kali ditanami cabai merah. Menurut Madden et al. (2007), jika suatu tanaman ditanam setiap tahun di daerah tertentu berulang-ulang, hal tersebut dapat mengarah pada akumulasi galur patogen dan membangun inokulum untuk penyakit tertentu. Pada kebun cabai merah milik petani di sekitar tempat penelitian juga terdapat beberapa tanaman yang terserang antraknosa. Berdasarkan hasil pengamatan mikroskopis Putro et al. (2014), jenis jamur yang menginfeksi adalah spesies Colletotrichum capsici. Hasil pengamataan penangkap spora yang diletakkan di sekitar tempat penelitian, menunjukkan terdapat konidia jamur penyebab antraknosa (Tabel 9) yaitu spesies Colletotrichum acutatum (Sym 2013).

Tabel 6 Jumlah konidia pada penangkap spora di lapangan

\begin{tabular}{cc}
\hline Pengamatan & Jumlah Konidia \\
\hline 15 HSPT & 13 \\
22 HSPT & 7 \\
29 HSPT & 12 \\
36 HSPT & 9 \\
43 HSPT & 8 \\
50 HSPT & 10 \\
57 HSPT & 6 \\
64 HSPT & 4 \\
71 HSPT & 4 \\
\hline
\end{tabular}

Faktor kedua yaitu terdapat tanaman inang yang rentan. Jenis cabai merah yang digunakan pada penelitian ini yaitu cabai merah varietas Gada F1. Berdasarkan hasil penelitian yang telah dilakukan oleh Muamaroh (2018), persentase kejadian penyakit cabai merah varietas gada sebesar 66,96\% (rentan) pada buah hijau dan 23,77\% (moderat).

Faktor ketiga yaitu lingkungan yang mendukung berkembangnya patogen. Selama penelitian berlangsung, kondisi kelembapan udara termasuk dalam kategori normal yaitu $75-85 \%$. Curah hujan pada bulan April masuk dalam 
kategori sangat tinggi ( $>500 \mathrm{~mm} /$ bulan$)$, pada bulan Mei dan Juni masuk kategori normal (100-300 $\mathrm{mm} /$ bulan), tetapi pada saat fase pembuahan tanaman (bulan Juli), curah hujan termasuk ke dalam kategori rendah $(0-100 \mathrm{~mm} /$ bulan $)$ (Tabel 1) karena telah memasuki musim kemarau (BMKG 2019). Menurut Hamidson et al. (2012), serangan antraknosa lebih sering terjadi pada musim penghujan. Spora jamur memerlukan kondisi kelembapan udara yang tinggi dan basah untuk perkecambahan dan proses infeksi terhadapa tanaman, namun jika kondisi lingkungan yang tidak diinginkan seperti yang disebutkan, spora akan gagal untuk berkecambah sehingga meniadakan peluang penyakit (Nega et al. 2016).

Terdapat satu faktor tambahan yaitu manusia. Manusia dapat berperan dalam menghambat atau mempercepat timbulnya suatu penyakit pada tanaman (Francl 2001). Contoh peran manusia dalam menghambat yaitu dengan melakukan pemuliaan terhadap suatu tanaman sehingga menghasilkan kultivar yang tahan penyakit (Noman et al. 2016) atau aplikasi bahan kimia (fungisida) untuk mengendalikan perkembangan patogen (Islam 2018). Sedangkan contoh peran manusia dalam mempercepat yaitu pada praktik budidaya seperti faktor irigasi dengan air yang telah terkontaminasi patogen (Francl 2001). Pada penelitian ini, terdapat upaya manusia dalam menghambat terjadinya serangan antraknosa yaitu dengan memberikan perlakuan fungisida nabati dari daun mimba dan mikroorganisme berupa MOL bonggol pisang. Namun, tingkat penghambatan perlakuan tersebut belum bisa diketahui, karena tidak terjadi serangan antraknosa pada semua tanaman termasuk perlakuan kontrol. Beberapa penelitian sebelumnya menunjukkan bahwa pemberian ekstrak bagian tanaman mimba dan mikroorganisme dapat menghambat terjadinya serangan penyakit pada tanaman. Penelitian Ali et al. (2012), menunjukkan bahwa ekstrak daun mimba dengan konsentrasi 20\% mampu menghambat pertumbuhan koloni jamur Colletotrichum capsici secra in vitro sebesar 20,12\% dan mampu menurunkan intensitas serangan antraknosa dengan nilai $27,40 \%$. Tanaman mimba telah digunakan sebagai agen biokontrol selama berabad-abad di Asia yang memiliki potensi antifungi. Agustin et al. (2016), menyatakan bahwa senyawa nimbin dan nimbidin yang terkandung dalam ekstrak daun mimba mempunyai efek fungisidal yang tinggi sehingga menyebabkan pertumbuhan miselium patogen menjadi terhambat.

Dalam MOL bonggol pisang terdapat mikroba antagonis yang dapat menghambat penyakit, salah satunya adalah Bacillus sp. (Arwiyanto et al. 2009). Bacillus sp. mengeluarkan senyawa antimikrob yaitu subtilin, subtilosin, basitrasin, streptovidin basilomisin, fengimisin, mikobasilin, mikosubtilin, polimiksin, zwitermisin A, difisidin dan mikoserein yang bersifat antifungi (Soesanto 2008).

Kejadian suatu penyakit yang menyerang tanaman dipengaruhi oleh tiga faktor utama yaitu tanaman inang (host), patogen dan lingkungan, yang dikenal dengan konsep segitiga penyakit (disease triangle) (Islam 2018). Suatu penyakit dapat terjadi jika terdapat tanaman inang yang rentan, patogen yang ganas (virulent) dan lingkungan yang mendukung untuk perkembangan patogen (Agrios 2005). Jika ketiga faktor tersebut tidak terpenuhi, maka tidak akan terjadi suatu penyakit (Islam 2018). Beberapa ahli patologi tanaman menguraikan segitiga penyakit dengan menambahkan parameter tambahan, seperti aktivitas manusia, vektor penyakit, dan waktu (Francl 2001). Tidak terjadinya serangan antraknosa pada penelitian ini diduga karena terdapat satu faktor utama penyebab penyakit yang tidak terpenuhi yaitu lingkungan yang tidak memungkinkan untuk berkembangnya patogen (Colletotrichum sp.). 


\section{Komponen Hasil Panen}

Konsentrasi MOL bonggol pisang hanya memberikan pengaruh yang nyata pada peubah bobot buah per tanaman tapi tidak pada peubah komponen hasil lainnya. Mikroba yang terkandung dalam MOL bonggol pisang seperti Bacillus, Azotobacter, Aspergillus niger dan Azospirillum diduga juga berperan dalam meningkatkan hasil tanaman (Budiyani et al. 2016). Toago et al. (2017), menyatakan bahwa inokulasi Azotobacter sp. atau Azospirillum dalam jumlah yang signifikan baik pada tanah maupun pada biji efektif dalam meningkatkan partumbuhan dan hasil tanaman budidaya. Bacillus sp. merupakan bakteri pelarut fosfat yang dapat meningkatkan unsur $\mathrm{P}$ tanah menjadi bentuk tersedia. Aspergillus niger termasuk dalam kelompok fungi pelarut fosfat yang mempunyai peranan seperti bakteri pelarut fosfat. Unsur $\mathrm{P}$ berperan penting dalam proses pembungaan dan pembuahan tanaman. Unsur $\mathrm{P}$ juga berpengaruh terhadap kekerasan buah sehingga dapat mempengaruhi bobot buah (Suhastyo 2011).

Meski bobot buah menunjukkan hasil yang berbeda nyata, namun pada peubah komponen hasil lainnya tidak nyata. Hal tersebut diduga karena pengaruh lingkungan. Temperatur udara maksimum selama penelitian mencapai $34,1{ }^{\circ} \mathrm{C}$ (Tabel 1). Menurut Ashari (2006), temperatur malam di bawah $16^{\circ} \mathrm{C}$ dan temperatur siang di atas $23^{\circ} \mathrm{C}$ dapat menghambat pembungaan dan menggagalkan pembuahan. Temperatur yang tinggi menyebabkan transpirasi berlebihan, sehingga tanaman kekurangan air yang mengakibatkan bunga dan buah mudah gugur.

\section{KESIMPULAN}

Hasil penelitian ini menunjukkan bahwa konsentrasi larutan daun mimba tidak memberikan pengaruh yang nyata terhadap semua peubah yang diamati. Konsentrasi larutan MOL bonggol pisang
45\% berpengaruh nyata dalam meningkatkan tinggi tanaman, jumlah daun, jumlah cabang produktif dan bobot buah per tanaman dibandingkan dengan perlakuan kontrol, namun tidak berbeda nyata dibandingkan dengan konsentrasi $30 \%$. Tidak terjadinya serangan antraknosa diduga karena faktor lingkungan yang tidak mendukung untuk perkembangan jamur Colletotrichum sp.

\section{DAFTAR PUSTAKA}

Agrios G. 2005. Plant Pathology 5th Edition. Amsterdam: Elsevier Academic Press.

Agustin S, Asrul A, Rosmini R. 2016. Efektivitas ekstrak daun mimba (Azadirachta indica A. Juss) terhadap pertumbuhan koloni Alternaria porri penyebab penyakit bercak ungu pada bawang wakegi (Allium $x$ wakegi Araki) secara in vitro.J. Agrotekbis 4 (4): 419 424.

Ali M, Venita Y, Rahman B. 2012. Uji beberapa konsentrasi ekstrak daun mimba (Azadirachta indica A. Juss.) untuk pengendalian penyakit antraknosa yang disebabkan jamur Colletotrichum capsisi pada buah cabai merah pasca-panen. JOM Pertanian Unri. 1 - 14.

Amadioha AC. (2000). Controlling rice blast in vitro and in vivo with extracts of Azadirachta indica. Crop Protection. 5: $287-290$.

Arwiyanto T, Chrisnawati C, Nasrun N. 2009. Pengendalian penyakit layu bakteri nilam menggunakan Bacillus sp. dan Pseudomonas flourescens. Litri. 15 (3): 116 123.

Ashari S. 2006. Hortikultura: Aspek Budidaya. Jakarta: Universitas Indonesia.

Badan Meteorologi, Klimatologi dan Geofisika. 2019. Data Online, Pusat Database BMKG. 
http://dataonline.bmkg.go.id/data_i klim. [13 Agustus 2019].

Badan Penelitian dan Pengembangan Pertanian. 2016. Pengendalian Penyakit Antraknose Pada Tanaman Cabai. http://www.litbang.pertanian.go.id/ info-teknologi/2630/. [16 Maret 2019.]

Badan Pusat Statistik. 2018. Statistik Tanaman Sayuan dan Buahbuahan Semusim Indonesia 2017. Jakarta: Badan Pusat Statistik.

Budiyani NK, Soniari NN, Sutari NSR. 2016. Analisis kualitas larutan mikroorganisme lokal (MOL) bonggol pisang. J. Agrotek. Tropika. 5 (1): 63 - 72.

Endah J dan Novizan N. 2002. Mengendalikan Hama dan Penyakit Tanaman. Depok: Agromedia Pustaka.

Francl LJ. 2001. The Disease Triangle: A plant pathological paradigm revisited.

https://www.apsnet.org/edcenter/fo reducators/TeachingNotes/Pages/D iseaseTriangle. [20 Agustus 2019].

Hamidson H, Umayah A, Suparman SHK, Muslim A. 2012. Perkembangan penyakit antraknosa cabai (Capsicum annuum L.) pada musim kemarau dan hujan di sentra produksi sumatera selatan. Prosiding Seminar Nasional Membangun Negara Agraris yang Berkeadilan dan Berbasis Kearifan Lokal. Surakarta: Fakultas Pertanian, Universitas Sebelas Maret. 427 - 439.

Islam W. 2018. Plant disease epidemiology: disease triangle and forecasting mechanisms in highlights. Hosts and Viruses. 5 (1): $7-11$.

Kurniati F, Sudartini T, Hidayat D. 2017. Aplikasi bebagai bahan zpt alami untuk meningkatkan pertumbuhan bibit kemiri sunan (Reutealis trisperma (Blanco) Airy Shaw). Jurnal Agro. 4 (1): 40 - 49.

Madden L, Gareth H, Frank VDB. 2007. Study of Plant Disease Epidemics. American Phytopathological Society.

Muamaroh S, Respatijarti R, Wahyono A. 2018. Tingkat ketahanan varietas cabai merah (Capsicum annuum L.) hibrida pada kemasakan buah terhadap penyakit antraknosa Colletotrichum acutatum. J. Prod. Tan.. 6 (4): $619-628$.

Nasrun N dan Nurmansyah. 2015. Potensi rizobakteria dan fungisida nabati untuk pengendalian penyakit jamur akar putihtanaman karet. Jurnal TIDP. 2 (2): $61-68$.

Nega A, Lemessa F, Berecha G. 2016. Distribution and importance of maize grey leaf spot Cercospora zeae-maydis (Tehon and Daniels) in south and southwest ethiopia. Journal of Plant Pathology and Microbiology. 7 (2): 1 - 7.

Noman A, Bashir R, Aqeel M, Anwer S, Iftikhar W, Zainab M, Zafar S, Khan S, Islam $\mathrm{W}$ and Adnan $\mathrm{M}$. 2016. Success of transgenic cotton (Gossypium hirsutum L.): fiction or reality?. Cogent Food and Agriculture. 1 - 13.

Nursyamsi N, Suhartati S, Abd QT. 2007. Pengaruh zat pengatur tumbuh pada perbanyakan jati muna secara kultur jaringan. J. Penelitian Hutan dan Konservasi Alam. 4 (4): 385 390.

Prasetyo A. 2017. Pemanfaatan kitosan untuk pengendalian penyakit antraknosa (Colletotrichum sp.) pada cabai (Capsicum annuum L.) [Skripsi]. Bogor: Fakultas Pertanian, Institut Pertanian Bogor.

Putro NS, Aini LQ, Abadi AL. 2014. Pengujian konsorium mikroba antagonis untuk mengendalikan penyakit antraknosa pada cabai merah besar (Capsicum annuum L.). Jurnal HPT. 2 (4): 44 - 53. 
Santosa E. 2008. Peranan Mikro Organisme Lokal dalam Budidaya Tanaman Padi Metode Sysytem of Rice Intensification. Jakarta: Departemen Pertanian.

Soesanto L. 2008. Pengantar Pengendalian Hayati Penyakit Tanaman. Jakarta: Rajagrafindo Persada

Suhastyo AA. 2011. Studi mikrobiologi dan sifat kimia mikroorganisme lokal (MOL) yang digunakan pada budidaya padi metode SRI (System of Rice Intensification). [Tesis]. Bogor: Sekolah Pascasarjana, Institut Pertanian Bogor.

Suleiman MN. 2010. Fungitoxic activity of neem and pawpaw leaves extracts on Alternaria solani, causal organism of yam rots. Adv. in Env. Biology. 4 (2): 159 - 16.

Susanto A, Sudharto PS, Purba RY. 2005. Enhancing biological control of basal stem rot disease (Ganoderma boninense) in oil palm plantations. Journal of Mycopathologia. 159:153 - 157 .
Sym KB. 2013. Morphological characterization, molecular identification and pathotyping of Cholletotrichum species in malaysia. [Disertasi]. Kuala Lumpur: Faculty of Sciences, University of Malaya.

Toago Sp, Lapanjang IM, Barus HN. 2017. Aplikasi kompos dan Azotobacter sp. terhadap pertumbuhan dan produksi tanaman cabai merah (Capsicum annuum L.). J. Agrotekbis. 5 (3): $291-299$.

Waskito H, Nuraini A, Rostini N. 2018. Respon pertumbuhan dan hasil cabai keriting (Capsicum annuum L.) Ck5 akibat perlakuan pupuk NPK dan pupuk hayati. Jurnal Kultivasi. 17 (2): $676-681$.

Wea MK. 2018. Pengaruh pupuk organik cair bonggol pisang kepok (Musa accuminate L.) terhadap pertumbuhan tanaman okra merah (Abelmoschus caillei). [Skripsi]. Yogyakarta: Fakultas Keguruan dan Ilmu Pendidikan, Universitas Sanata 